\title{
CANCER MORTALITY TRENDS IN BRAZILIAN ADULTS AGED 80 AND OVER FROM 2000 TO 2017
}

\section{Tendência da mortalidade por neoplasias malignas em idosos brasileiros com mais de 80 anos entre 2000 e 2017}

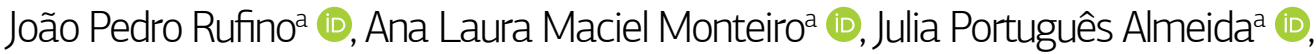 \\ Karolina Moreira dos Santos ${ }^{\mathrm{a}}$, Mariana da Cruz Andrade ${ }^{\mathrm{a}}$ (D), Silvia Cristina Marques Nunes Pricinote ${ }^{\mathrm{a}}$
}

$\vdash$

U

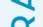

$\stackrel{1}{\vdash}$

m

$<$

$\underset{\sim}{\sim}$

INTRODUCTION: Adults aged 80 and over represent the fastest growing segment of the population in emerging countries. Studies of cancer mortality trends in the oldest old population are scarce in Brazil. OBJECTIVE: To describe trends in cancer mortality in the Brazilian oldest old, by gender and cancer type, from 2000 to 2017. METHODS: This was a descriptive study with a time trend design, based on data from the Mortality Information System (of the Informatics Department of the Unified Health System). The variables analyzed were year of death, sex and cancer site. The five most common types of cancer were identified, and mortality rates and trends were calculated for each one. Trends were determined using joinpoint regression. In all cases where one or more joinpoints were statistically significant, the average annual percent change (AAPC) was calculated based on the arithmetic mean of the annual percent change (APC), weighted by the length of each segment. The statistical significance of the APC and AAPC was estimated by calculating 95\% confidence intervals (CI) with an alpha level of 0.05. RESULTS: Mortality rates increased over time (AAPC = 1.50; 95\%Cl, $1.20-1.70$ ) in both males (AAPC $=1.90 ; 95 \% \mathrm{Cl}, 1.70-2.10)$ and females ( $\mathrm{AAPC}=1.30 ; 95 \% \mathrm{Cl}, 1.00-1.50)$. Men had higher mortality rates than women. The most common causes of cancer-related death were prostate cancer (AAPC $=1.70 ; 95 \% \mathrm{Cl}, 1.10-2.30)$ in men, and breast cancer (AAPC = 1.90; 95\%Cl, $1.50-2.20$ ) in women, followed by cancers of the lung and bronchus, stomach and colon. All rates increased over time, except in the case of stomach cancer. CONCLUSION: The study revealed increasing mortality rates for screenable and/or preventable cancers, alerting to the need for preventive measures.

KEYWORDS: cancer; aged 80 and over; mortality.

INTRODUÇÃO: Idosos com 80 anos ou mais representam o segmento populacional com o maior crescimento proporcional em países emergentes. Investigações abordando a tendência de mortalidade por neoplasias malignas na população muito idosa no Brasil são escassas e incomuns. OBJETIVO: Descrever a tendência de óbitos por câncer na população muito idosa, por sexo e tipo, entre 2000 e 2017 no Brasil. METODOLOGIA: Estudo descritivo, tipo tendência, com uso de dados secundários do Sistema de Informações sobre Mortalidade (do Departamento de Informática do Sistema Único de Saúde). As variáveis foram ano de óbito, sexo e sítio da neoplasia. Os cinco principais tipos de neoplasia foram determinados, e foram calculadas as taxas de mortalidade e tendência específicas. A tendência foi determinada por modelo de regressão joinpoint. Nos casos em que se identificaram um ou mais joinpoints, calculou-se a variação percentual anual média, do inglês average annual percent change (AAPC), por meio da média geométrica ponderada das variações percentuais anuais (APCs, do inglês annual percent change) na qual os pesos foram equivalentes aos comprimentos dos segmentos. Estimou-se a significância estatística da APC/AAPC pelo cálculo dos seus respectivos intervalos de confiança de 95\% (IC95\%), considerando alfa de 0,05. RESULTADOS: Foi observada uma tendência crescente da taxa de mortalidade (AAPC = 1,50; IC95\% 1,20 - 1,70), no sexo masculino (AAPC = 1,90; IC95\% 1,70 - 2,10) e feminino (AAPC = 1,30; IC95\% 1,00 - 1,50). Maiores taxas de mortalidade concentraram-se em homens. Os sítios de câncer que mais causaram mortes foram próstata (AAPC = 1,70; IC95\% 1,10 - 2,30), em homens, e mama (AAPC = 1,90; IC95\% 1,50 - 2,20), em mulheres, seguidos por brônquios e pulmões, estômago e cólon, todos com taxas crescentes - exceto estômago. CONCLUSÕES: Observaram-se taxas crescentes de neoplasias rastreáveis e/ou preveníveis, alertando sobre necessidade de medidas preventivas.

PALAVRAS-CHAVE: neoplasias; idoso de 80 anos ou mais; mortalidade.

aFaculdade de Medicina, Universidade Federal de Goiás - Goiânia (GO), Brazil.

Correspondence data

João Pedro Rufino - Rua 235, s/n - Setor Leste Universitário - CEP: 74605-050 - Goiânia (GO), Brazil. E-mail: joao.pedro.rufino3@gmail.com Received on: 07/08/2020. Accepted on: 20/10/2020

https://doi.org/10.5327/Z2447-212320202000097 


\section{INTRODUCTION}

According to the World Health Organization and the National Cancer Institute, the global cancer burden has doubled in the past 30 years. In 2020, it is estimated that 15 million new cases of cancer will be diagnosed, and that approximately $75 \%$ of these will affect individuals older than 60 years. ${ }^{1}$

Though there is some disagreement on the matter, age is still seen as an independent risk factor for cancer. Longevity is associated with greater exposure to risk factors for tumor formation, such as sunlight and radiation, alcohol and tobacco use, environmental pollution, poor diet and infections that may lead to cancer. ${ }^{2}$ However, the accumulation of age-related damage varies significantly between tissues, contributing to the diversity of neoplastic processes. ${ }^{3}$ Cancer is caused by uncontrolled cell proliferation as a result of genomic instability; this is especially likely to occur after exposure to risk factors for deoxyribonucleic acid (DNA) damage. ${ }^{4}$ The transformation of normal cells into cancer cells is a multifactorial process, which includes the accumulation of DNA damage and mutations over time, as well as disruptions in DNA repair and cell growth regulation.,3

Population aging has made a substantial contribution to the global increase in the incidence of cancer. ${ }^{5}$ In Latin America, for instance, the number of older adults is expected to double in less than 20 years, and 1.2 million cases of cancer are expected to be diagnosed in this population in $2035 .{ }^{6}$ In 2018 , nearly $59 \%$ of new cancer cases and two thirds of cancer-related deaths in Brazil occurred in older adults. ${ }^{7}$

These individuals represent the fastest growing age segment of the Brazilian population. Within this age bracket, the oldest old — individuals aged 80 and over — have exhibited the greatest population growth. According to the Brazilian Institute of Geography and Statistics (IBGE), the age group known as the oldest old is expected to grow by $540 \%$, from 3 million in 2010 to over 19 million in $2060 .{ }^{8}$ Furthermore, the demographic and epidemiological transitions associated with the progressive aging of the Brazilian population will lead to changes in the cancer sites with the greatest number of deaths among older adults. This, in turn, will affect cancer-related morbidity and mortality. ${ }^{9}$

Despite the importance of this issue, few Brazilian studies have described or assessed changes in the trends of cancer morbidity and mortality in adults aged 80 and over. This knowledge gap results in a lack of initiatives and public policies to address the specific needs of these individuals. ${ }^{10}$ Given the need for a better comprehension of the epidemiological dynamics of cancer in this age group, the aim of this study was to describe the trends in death rates due to malignant neoplasms in the oldest old population from 2000 to 2017 in Brazil.

\section{METHODS}

This was a descriptive study with a time trend design. National data on deaths due to malignant neoplasms in patients aged 80 and over from January 2000 to December 2017 in Brazil were obtained from the Mortality Information System; these records are available on the website of the Informatics Department of the Unified Health System, managed by the Brazilian Ministry of Health. All deaths with International Classification of Diseases (ICD)-10 codes C00 to C97 in individuals aged 80 and over were included in this study. Demographic data were obtained from the IBGE.

The variables analyzed were year of death, sex and cancer site ( $\mathrm{C} 00$ to $\mathrm{C} 97)$. Annual mortality rates were calculated for the total sample and by gender. Additionally, the five most common cancer sites in each gender were identified, in order to calculate the mortality rates and trends for each of these diagnoses.

Cancer mortality trends over time were analyzed using joinpoint regression to compute the annual percent change in these values. These models can be used to identify significant changes in the trends. ${ }^{11}$ In joinpoint regression, straight lines are placed on a logarithmic scale in order to identify annual trends in the dependent variable. The slope of each segment is then used to calculate the annual percent change (APC). The year was used as the independent variable, while mortality rates were the dependent variables. In all cases where one or more joinpoints were statistically significant, suggesting two or more changes in the trend patterns, the average annual percent change (AAPC) was calculated based on the arithmetic mean of the APC, weighted by the length of each segment. ${ }^{12}$ The statistical significance of the APC and AAPC was estimated by calculating $95 \%$ confidence intervals (CI) with an alpha level of $0.05 .^{11,12}$

The trend was considered to be increasing when the APC/AAPC were greater than zero (positive), and the lower bound of the $95 \% \mathrm{CI}$ was above zero. A decreasing trend was observed when the APC/AAPC was lower than zero (negative), and the upper bound of the $95 \% \mathrm{CI}$ was above zero. Rates with an APC/AAPC of zero and/or a 95\%CI that included zero were considered stable. ${ }^{11,12}$

The data were entered into spreadsheets and tables were generated using Microsoft Excel. Statistical procedures were performed using the Joinpoint Regression Program, version 4.7.0.0. ${ }^{13,14}$ 
The study did not require approval by a research ethics committee since it involved only secondary data, available on the public domain, with no identifying information.

\section{RESULTS}

From 2000 to 2017, 538439 cancer deaths among individuals aged 80 and over were reported in Brazil. Men accounted for $53 \%$ of these deaths. Mortality rates ranged from 956.86 deaths per 100000 population in 2000, at the start of the study period, to 1215.86 deaths per 100 000 in 2017. This represents an overall increase in death rates $(\mathrm{AAPC}=1.50 ; 95 \% \mathrm{CI}, 1.20-1.70)$. These figures increased steadily until 2007 , then remained stable for the rest of the study period.

When data were stratified by sex, results showed that most deaths in women were caused by cancers of the breast (11.07\%), lung and bronchus (8.81\%), stomach (7.73\%), colon (7.51\%) and pancreas (6.15\%) (Figure 1). When all types of cancer were combined, mortality rates for women ranged from 756.21 deaths per 100000 to 929.61 per 100 000 population.

Time trend analysis showed that mortality rates due to breast, lung and bronchus, colon and pancreatic cancer increased consistently over time. Deaths due to stomach cancer, however, showed a decrease, especially after 2006 (Tables 1 and 2).

Mortality rates for men showed that most deaths in these individuals were caused by prostate $(30.53 \%)$, lung and bronchus (11.80\%), stomach (8.66\%), colon (4.27\%) and bladder cancer (4.16\%) (Figure 2). Overall mortality rates in men used ranged from 1265.22 per 100000 population in 2000 to 1691.38 per 100000 in 2017, reflecting a significant increase over the study period $(\mathrm{AAPC}=1.90$; $95 \% \mathrm{CI}, 1.70-2.10)$. These rates rose most sharply at the start of the study period, from 2000 to 2017 (APC = 4.30; 95\%CI, $3.70-4.80$ ).

Among males, mortality increased over time for all types of cancer, except for stomach cancer. Despite increasing throughout the study period, mortality rates due to bronchus and lung cancer showed a reduction in APC starting in 2007, which indicates a decrease in annual growth rates. Similarly, prostate cancer rates rose sharply at the start of the decade, but reversed course in 2010 with a negative APC, indicating a reduction in mortality rates that was subtle enough not to influence the AAPC. In men, as in women, mortality rates due to stomach cancer decreased from 2005 to 2006, changing from stable to decreasing (Tables 1 and 2).

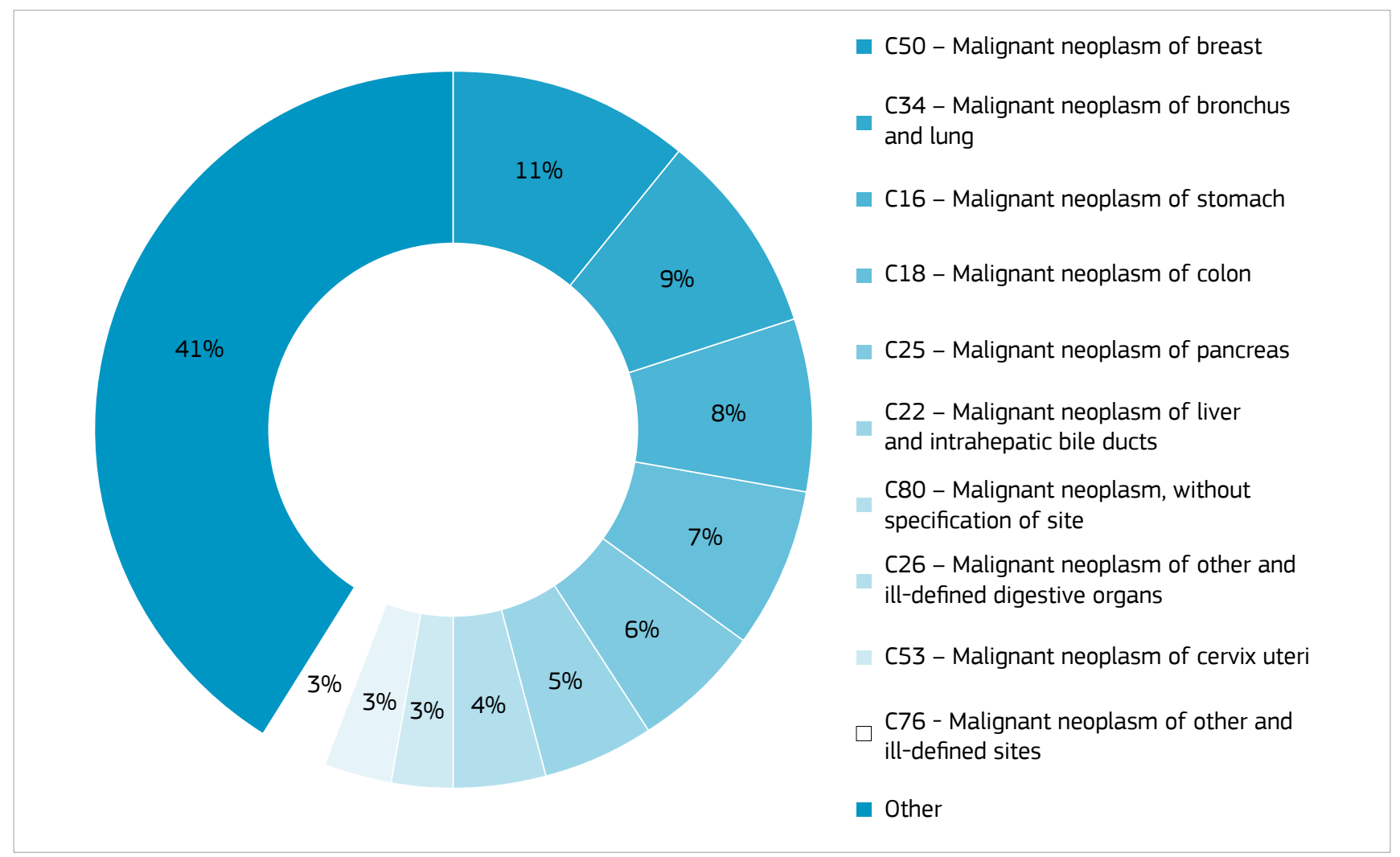

Figure 1. Distribution of deaths by cancer type in women aged 80 and over, 2000-2017, Brazil. 


\section{DISCUSSION}

The results showed an increase in cancer rates in adults aged 80 and over during the study period. Men had higher mortality rates than women, and the types of cancer associated with the greatest number of deaths were prostate in males and breast in females, followed - in both genders - by cancers of the lung and bronchus, stomach and colon. Mortality rates for all cancer sites except the stomach increased during the study period.

The mortality rates in individuals aged 80 and over were higher than those observed in other age groups, which range from 752 to 1103 deaths per 100000 population in the United States and Canada. ${ }^{15,16}$ This was an expected finding, since age is considered a risk factor for several types of cancer.

A population-based study of young-old adults (approximately 65 years) in England found that most cancer deaths in this population were attributed to lung $(22.10 \%)$, colon and rectum (10.60\%) and breast cancer (8.50\%). ${ }^{15}$ Similarly, a multinational study of individuals aged 65 or older in North America, Europe and Russia observed that colon and rectum, lung, breast and prostate cancer were the most common types of cancer leading to death. ${ }^{15} \mathrm{~A}$ separate study performed in the United States involving adults over 85 years of age noted that the most commonly diagnosed cancers in these individuals were lung, breast, prostate and colon cancer; the frequency of these diagnoses did not differ from that seen in the general population. ${ }^{17}$ The types of cancer most commonly leading to death were also similar between young-old adults and those older than 80 years.

The present study found a trend of increasing mortality in adults over 80 years. This result differs from those observed in North-American populations, where the rates for individuals older than 85 years peaked in the 1990s, but decreased over the past decade. ${ }^{17}$ The study that produced this finding attributed the decline to the decrease in mortality rates associated with prostate and lung cancer. On a similar vein, a multinational study performed in North America, Europe and Russia revealed a reduction in mortality rates for individuals of both genders aged 65 years or older. ${ }^{15}$

Men had higher mortality rates than women throughout the study period, corroborating the findings of previous studies of older adults. ${ }^{15,16}$ These gender differences may be attributed to the community living behaviors of men with

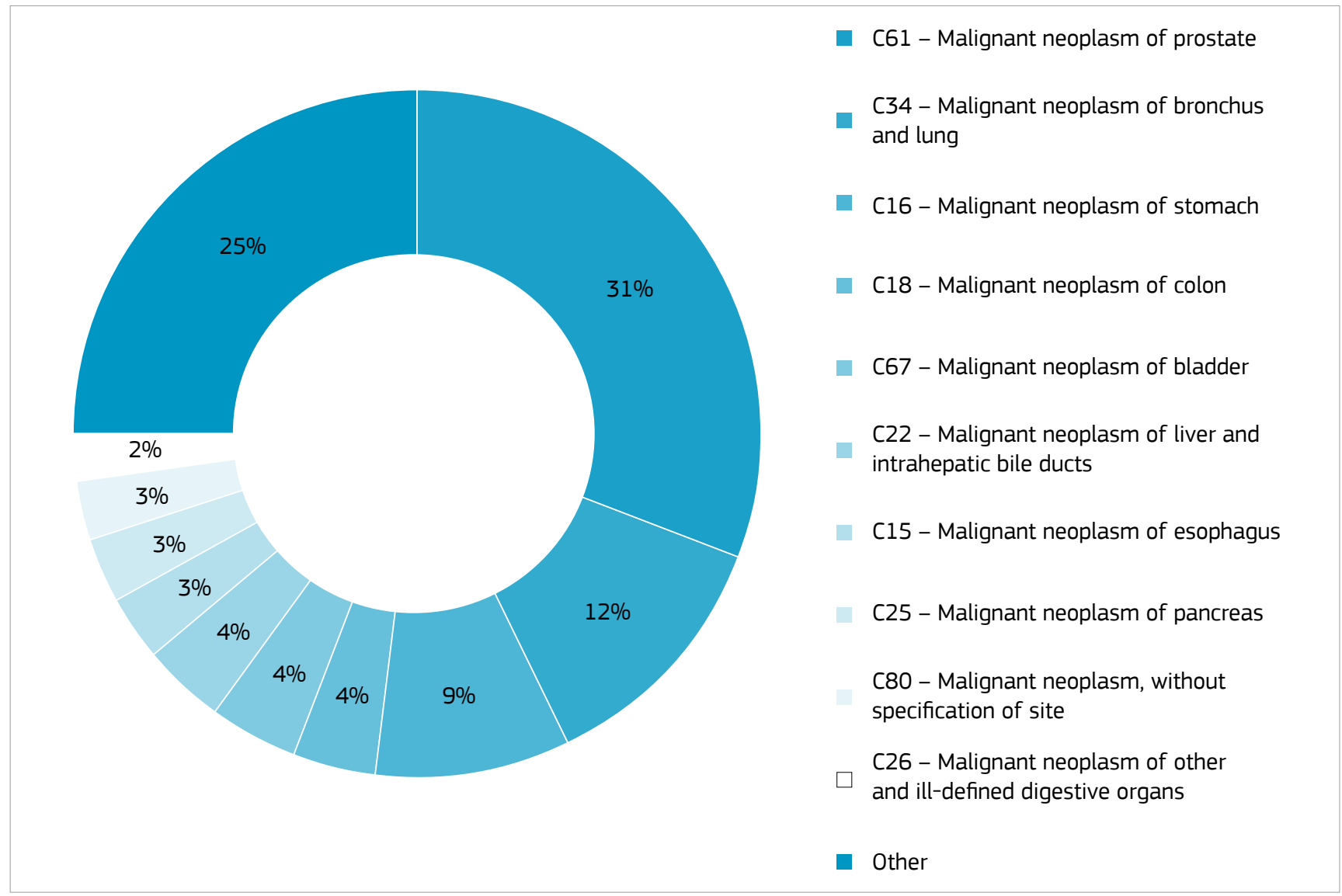

Figure 2. Distribution of deaths by cancer type in men aged 80 and over, 2000-2017, Brazil. 
respect to comorbidities and risk factors (smoking, alcohol use, etc.). The social roles and behavior patterns supposedly associated with masculinity have a direct link to the higher incidence of illness and lower utilization of health care services, both of which result in higher mortality rates. ${ }^{18}$

The present findings also revealed an increasing trend in mortality due to prostate cancer at the start of the study period, though these metrics reached a plateau in 2006. Starting in 2010, mortality rates due to prostate cancer showed a decreasing trend. In the 1990s, nearly one decade before the start of the study period, prostate-specific antigen screening strategies were implemented in more developed countries as well as in Brazil, in order to reduce mortality at more advanced stages of the illness. As such, the increased

Table 1. Annual percent change and joinpoints in cancer mortality rates among adults aged 80 and over, by gender and type of cancer (within each gender), 2000-2017, Brazil.

\begin{tabular}{l|c|c|c|c|c|c|c|c} 
Variable & APC1 & $\begin{array}{c}95 \% \mathrm{Cl} \\
{[\mathrm{LL} ; \mathrm{UL}]}\end{array}$ & Joinpoint & APC2 & $\begin{array}{c}95 \% \mathrm{Cl} \\
{[\mathrm{LL} ; \mathrm{UL}]}\end{array}$ & Joinpoint & APC3 & $\begin{array}{c}95 \% \mathrm{Cl} \\
{[\mathrm{LL} ; \mathrm{UL}]}\end{array}$ \\
\hline Female & $2.74^{*}$ & {$[2.10 ; 3.30]$} & 2007 & 0.23 & {$[-0.01 ; 0.50]$} & - & - & - \\
\hline Breast & $2.98^{*}$ & {$[2.20 ; 3.80]$} & 2007 & $1.07^{*}$ & {$[0.70 ; 1.40]$} & - & - & - \\
\hline Lung and bronchus & $3.86^{*}$ & {$[3.10 ; 4.60]$} & 2008 & $2.53^{*}$ & {$[2.10 ; 3.00]$} & - & - & - \\
\hline Stomach & 0.99 & {$[-1.50 ; 3.50]$} & 2006 & $-2.62^{*}$ & {$[-3.50 ;-1.80]$} & - & - & - \\
\hline Colon & $1.25^{*}$ & {$[0.90 ; 1.60]$} & - & - & - & - & - & - \\
\hline Pancreas & $2.16^{*}$ & {$[1.80 ; 2.60]$} & - & - & - & - & - & - \\
\hline Male & $4.28^{*}$ & {$[3.70 ; 4.80]$} & 2007 & $0.25^{*}$ & {$[0.01 ; 0.50]$} & - & - & - \\
\hline Prostate & $5.80^{*}$ & {$[4.80 ; 6.80]$} & 2006 & 1.08 & {$[1.10 ; 3.30]$} & 2010 & $-1.27^{*}$ & {$[-1.80 ;-0.80]$} \\
\hline Lung and bronchus & $3.97^{*}$ & {$[2.80 ; 5.10]$} & 2007 & $1.18^{*}$ & {$[0.70 ; 1.70]$} & - & - & - \\
\hline Stomach & 2.46 & {$[-0.01 ; 5.00]$} & 2005 & $-1.89^{*}$ & {$[-2.40 ;-1.30]$} & - & - & - \\
\hline Colon & $2.84^{*}$ & {$[2.40 ; 3.30]$} & - & - & - & - & - & - \\
\hline Bladder & $2.18^{*}$ & {$[1.80 ; 2.60]$} & - & - & - & - & - & - \\
\hline Total & $3.30^{*}$ & {$[2.90 ; 3.70]$} & 2007 & 0.57 & {$[-0.20 ; 1.30]$} & 2012 & -0.20 & {$[-0.70 ; 0.30]$} \\
\hline
\end{tabular}

APC: annual percent change; 95\%Cl: 95\% confidence interval; LL: lower limit of confidence interval; UL: upper limit of confidence interval; ${ }^{*} \mathrm{APC}$ is significantly different from zero, at alpha $=0.05$.

Table 2. Trends in annual percent change in cancer mortality rates among adults aged 80 and over, by gender and type of cancer (within each gender), 2000-2017, Brazil.

\begin{tabular}{l|c|c|c|c}
\hline Variable & AAPC & $95 \% \mathrm{CI}[\mathrm{LL} ; \mathrm{UL}]$ & $\mathrm{p}$-value & $\begin{array}{c}\text { Trend } \\
\text { Female }\end{array}$ \\
\hline Breast & $1.30^{*}$ & {$[1.00 ; 1.50]$} & $<0.01$ & Increase \\
\hline Lung and bronchus & $1.90^{*}$ & {$[1.50 ; 2.20]$} & $<0.01$ & Increase \\
\hline Stomach & $3.20^{*}$ & {$[2.80 ; 3.50]$} & $<0.01$ & Increase \\
\hline Colon & $-1.40^{*}$ & {$[-2.30 ;-0.40]$} & $<0.01$ & Decrease \\
\hline Pancreas & $1.20^{*}$ & {$[0.90 ; 1.60]$} & $<0.01$ & Increase \\
\hline Male & $2.20^{*}$ & {$[1.80 ; 2.60]$} & $<0.01$ & Increase \\
\hline Prostate & $1.90^{*}$ & {$[1.70 ; 2.10]$} & $<0.01$ & Increase \\
\hline Lung and bronchus & $1.70^{*}$ & {$[1.10 ; 2.30]$} & $<0.01$ & Increase \\
\hline Stomach & $2.30^{*}$ & {$[1.80 ; 2.80]$} & $<0.01$ & Increase \\
\hline Colon & -0.60 & {$[-1.40 ; 0.10]$} & 0.10 & Stable \\
\hline Bladder & $2.80^{*}$ & {$[2.40 ; 3.30]$} & $<0.01$ & Increase \\
\hline Total & $2.20^{*}$ & {$[1.80 ; 2.60]$} & $<0.01$ & Increase \\
\hline AAPC: ancrease
\end{tabular}

AAPC: annual percent change; 95\%Cl: 95\% confidence interval; LL: lower limit of confidence interval; UL: upper limit of confidence interval; *APC is significantly different from zero, at alpha $=0.05$. 
mortality in older adults at the start of the study period may be explained by the increased diagnosis of late-stage prostate cancer in cases where the cause of death would have otherwise been unknown. ${ }^{19,20}$

Deaths due to stomach cancer also decreased over the years in both genders. A similar decreasing trend was also observed by Carioli et al. ${ }^{15}$ in both genders, which is in contrast with findings in the United States, where stomach neoplasms are a less frequent cause of death and are not among the ten most common causes of cancer-related death. ${ }^{17}$ The downward trend observed in the present study may be attributable to a decrease in the prevalence of Helicobacter pylori ${ }^{21}$ infection; improvements in sanitation and in food processing and storage; higher fruit and vegetable intake; lower salt intake; and changes in smoking behaviors. ${ }^{22,23}$ The reduced mortality rates in these individuals may also be related to the new chemotherapy-based treatment strategies for gastric cancer implemented in recent decades. ${ }^{22,23}$

In women, breast cancer was the main cause of cancer-related death, and its associated mortality rate increased over the years. Similar trends have been observed in Poland, Russia and Japan, as reported in previous studies. ${ }^{15}$ In the North American population, a study found that patients diagnosed with breast cancer after the age of 85 years are less likely to be diagnosed at a local stage and have lower survival rates than patients in younger age groups. This may be due to the greater complexity of treating older patients; the presence of comorbidities; functional and cognitive impairment; as well as other risk factors and the deleterious effects of treatment. ${ }^{17}$

In both men and women, lung and bronchus cancers had a significant prevalence, which increased over the past decade. In the United States, mortality rate trends differ between genders, increasing in women but decreasing in men. ${ }^{17}$ In the present study, though both genders trended toward an increase, the rate of change was greater among females (AAPC $=3.2$ in women and $\mathrm{AAPC}=2.3$ in men). Smoking is responsible for over $90 \%$ of lung cancers, so that the evolution of mortality due to cancers of the bronchus and lungs in Brazil is associated with the epidemiology of smoking behavior. ${ }^{24,25} \mathrm{It}$ is possible that the increase in lung cancer in older adults may be due to their exposure to cigarette smoke during the period when smoking was most common in Brazil, which spanned the 1950s and 1960s, and peaked in the 1970s. ${ }^{25}$

Colon cancer was also a prevalent cause of death in individuals aged 80 years or older, with mortality rates increasing in both genders. A multinational study conducted by
Carioli et al. ${ }^{15}$ revealed that colorectal cancer rates were only increasing in Poland and Russia, with North America, Europe, Argentina and Japan showing a decrease in prevalence rates. A similar decrease was also observed in a separate study performed in the United States. ${ }^{17}$ One possible explanation for the increased mortality due to colorectal cancer in this age group is the greater incidence of the cancer itself due to changes in the lifestyle habits of the Brazilian population over recent decades. The main risk factors for colon cancer are diets with a high content of meat, fats and calories; a sedentary lifestyle; alcohol intake and smoking. ${ }^{26}$ A study of regional discrepancies in the growth of mortality rates due to colorectal cancer in Brazil from 1996 to 2012 showed that the largest increases in these figures occurred in the north and northeastern regions of the country. In recent decades, Brazilian states have experienced varying degrees of socioeconomic change, with the northern and northeastern states seeing the greatest decreases in inequality. Improved economic conditions are accompanied by changes in diet, so that higher incomes are often followed by increased consumption of processed foods, higher smoking rates and a more sedentary lifestyle. ${ }^{26}$

Patients diagnosed with colon cancer at an older age are often diagnosed at later stages of the illness and receive less aggressive treatment. ${ }^{27}$ Though age alone is not a contraindication to treatment, older patients with colon cancer usually receive less aggressive care. This is usually justified by the lack of documentation of the effects of chemotherapy in this age group, since older patients are often excluded from clinical trials. Recent studies have also demonstrated improved survival rates in older adults with stage III colon cancer. ${ }^{28}$

When interpreting the present findings, one must consider the possibility that the increased mortality rates are due to the population growth in this age group over recent years. The number of adults aged 80 years or older is increasing in Brazil, ${ }^{8}$ and several studies have demonstrated an association between population aging and an increase in cancer incidence, and consequently, mortality. ${ }^{5}$ As has been widely documented, older adults with cancer are at a higher risk of death than their cancer-free counterparts, which could explain the increase in mortality rates. ${ }^{29}$ Population aging has also been accompanied by a global improvement in diagnostic methods and access to health care in all age groups. Therefore, since a significant portion of octogenarians have functional limitations that preclude the use of some treatments, higher detection rates tend to increase cancer mortality, since the diagnosis provides a prior indication of the cause of death. ${ }^{17}$ 
The present study may have been limited by the use of secondary data from the Mortality Information System, which has improved in recent years but is still affected by underreporting. A study conducted in northeastern Brazil revealed that the correction of mortality data led to significant improvements in data quality, as well as an increase in the number of deaths associated with the most common types of cancer. ${ }^{30}$ Additionally, the descriptive design prevented the identification of risk factors.

\section{CONCLUSION}

The cancer mortality rates for adults aged 80 years or older increased during the study period. Most cancer-related deaths in this age group were caused by conditions for which screening tests are available, such as breast, prostate and colon cancer; or cancers that may be potentially prevented by healthy habits, such as lung and bronchus, colon and stomach cancers.

Given the projected increase in life expectancy over the next few years, and the subsequent growth in the older population, knowledge of the most common forms of cancer in these individuals is crucial to support the implementation of preventive health measures to reduce the incidence of these conditions or diagnose them before they become too severe. These data will also contribute to the investigation of treatments and techniques to improve survival in these patients.

\section{CONFLICTS OF INTEREST}

The authors declare no conflicts of interest.

\section{FUNDING}

None.

\section{AUTHOR CONTRIBUTIONS}

JPR: conceptualization, data curation, formal analysis, investigation, methodology, validation, project administration, visualization, writing - original draft, writing - review \& editing. ALMM: conceptualization, data curation, formal analysis, investigation, methodology, validation, project administration, visualization, writing - original draft. JPA: conceptualization, data curation, formal analysis, investigation, methodology, validation, project administration, visualization, writing - original draft. KMS: conceptualization, data curation, formal analysis, investigation, methodology, validation, project administration, visualization, writing original draft. MCA: conceptualization, data curation, formal analysis, investigation, methodology, validation, project administration, visualization, writing - original draft. SCMNP: supervision, conceptualization, data curation, formal analysis, investigation, methodology, validation, project administration, visualization, writing - original draft, writing - review \& editing.

\section{REFERENCES}

1. World Health Organization (WHO). Global cancer rates could increase by $50 \%$ to 15 million by 2020. WHO. Available from: http://www. who.int/mediacentre/news/releases/2003/pr27/en/. Accessed in Aug 28, 2020.

2. Danaei G, Vander Hoorn S, Lopez AD, Murray CJ, Ezzati M. Causes of cancer in the world: comparative risk assessment of nine behavioural and environmental risk factors. Lancet [Internet] 2005 [Accessed in 2020 Sep 19];366(9499):1784-93. https://doi.org/10.1016/S01406736(05)67725-2

3. Finkel T, Serrano M, Blasco MA. The common biology of cancer and ageing. Nature [Internet] 2007 [Accessed in 2020 Sep 19];448(7155):767-74. https://doi.org/10.1038/nature05985

4. Niccoli T, Partridge L. Ageing as a Risk Factor for Disease. Curr Biol [Internet] 2012 [Accessed in 2020 Sep 19];22(17):R741-52. https:// doi.org/10.1016/j.cub.2012.07.024

5. Pilleron S, Sarfati D, Janssen-Heijnen M, Vignat J, Ferlay J, Bray F, et al. Global cancer incidence in older adults, 2012 and 2035: A population-based study. Int J Cancer [Internet] 2019 [Accessed in 2020 Aug 25];144(1):49-58. https://doi.org/10.1002/ijc.31664

6. Soto-Perez-de-Celis E, de Glas NA, Hsu T, Kanesvaran R, Steer C, Navarrete-Reyes AP, et al. Global geriatric oncology: Achievements and challenges. J Geriatr Oncol [Internet] 2017 [Accessed in 2020 Aug 25];8(5):374-86. https://doi.org/10.1016/j. jgo.2017.06.001

7. Silva FC da, Araújo L da S, Frizzo MN. Neoplasias hematológicas no idoso: uma revisão. Rev Saúde Integr. 2015;8(15):1-13.
8. Instituto Brasileiro de Geografia e Estatística (IBGE). Projeção da população do Brasil e Unidades da Federação por sexo e idade para o período 2000-2030. Available from: http://www.ibge.gov.br. Accessed in 28 Aug, 2020.

9. Assis CMR, Melo HM de A, Melo EM de A, Kitner D, Costa Júnior J. Oncologia geriátrica: conceitos, tendências e desafios. Geriatr Gerontol Aging. 2011;5(2):106-11.

10. Fêde ABS, Miranda VC, Pecoroni PG, Fraile NMP, Santos MBB, Gonzaga SFR, et al. A importância das neoplasias na população idosa brasileira de 2000 a 2005. Einstein (São Paulo). 2009;7(2 Pt 1):141-6.

11. Rea F, Pagan E, Compagnoni MM, Cantarutti A, Pugni P, Bagnardi $V$, et al. Joinpoint regression analysis with time-on-study as timescale. Application to three Italian population-based cohort studies. Epidemiol Biostat Public Heal [Internet] 2017 [Accessed in 2020 Jul 25];14(3):e12616-1. https://doi.org/10.2427/12616

12. Kim H-J, Fay MP, Feuer EJ, Midthune DN. Permutation tests for joinpoint regression with applications to cancer rates. Stat Med [Internet] 2000 [Accessed in 2020 Jul 3]; 19(3):335-51. https://doi.org/10.1002/ (SICI) 1097-0258(20000215)19:3<335::AID-SIM336>3.0.CO;2-Z

13. National Cancer Institute. Joinpoint Regression Program. Version 4.8.0.1: programa de estatística jointpoint. Bethesda: Surveillance Research Program of National Cancer Institute; 2020.

14. Microsoft Office. Microsoft Excel. Versão 16.0: computer software for word processing, database, and statistics for micro-computers. Redmond: Microsoft Corporation; 2016. 
15. Carioli G, Malvezzi M, Bertuccio P, Hashim D, Waxman S, Negri E, et al. Cancer mortality in the elderly in 11 countries worldwide, 1970-2015. Ann Oncol [Internet] 2019 [Accessed in 2020 Aug 25];30(8):1344-55. https://doi.org/10.1093/annonc/mdz178

16. Gao W, Ho YK, Verne J, Glickman M, Higginson IJ. Changing Patterns in Place of Cancer Death in England: A Population-Based Study. PLoS Med [Internet] 2013 [Accessed in 2020 Aug 25];10(3):e1001410. https://doi.org/10.1371/journal.pmed.1001410

17. DeSantis CE, Miller KD, Dale W, Mohile SG, Cohen HJ, Leach CR, et al. Cancer statistics for adults aged 85 years and older, 2019. CA Cancer J Clin [Internet] 2019 [Accessed in 2020 Aug 25];69(6):45267. https://doi.org/10.3322/caac.21577

18. Oliveira MM de, Daher DV, Silva JLL da, Andrade SSC de A. Men's health in question: seeking assistance in primary health care. Cien Saude Colet [Internet] 2015 [Accessed in 2020 Jul 25];20(1):273-8. https://doi.org/10.1590/1413-81232014201.21732013

19. Braga SFM, de Souza MC, Cherchiglia ML. Time trends for prostate cancer mortality in Brazil and its geographic regions: An age-periodcohort analysis. Cancer Epidemiol [Internet] 2017 [Accessed in 2020 Aug 25];50(Pt A):53-9. https://doi.org/10.1016/j.canep.2017.07.016

20. Busato WFS, Almeida GL. Prostate cancer screening in Brazil: should it be done or not? Int Braz J Urol [Internet] 2016 [Accessed in 2020 Jul 25];42(6):1069-80. https://doi.org/10.1590/s1677-5538. ibju.2015.0709

21. Peleteiro B, La Vecchia C, Lunet N. The role of Helicobacter pylori infection in the web of gastric cancer causation. Eur J Cancer Prev [Internet] 2012 [Accessed in 2020 Jul 25];21(2):118-25. https://doi. org/10.1097/cej.0b013e32834a7f66

22. Sierra MS, Cueva P, Bravo LE, Forman D. Stomach cancer burden in Central and South America. Cancer Epidemiol [Internet] 2016 [Accessed in 2020 Aug 25]:44(Supl. 1):S62-73. https://doi. org/10.1016/j.canep.2016.03.008
23. Giusti ACBS, Salvador PTCO, Santos J, Meira KC, Camacho AR, Guimarães RM, et al. Trends and predictions for gastric cancer mortality in Brazil. World J Gastroenterol [Internet] 2016 [Accessed in 2020 Jul 25];22(28):6527-38. http://doi.org/10.3748/wjg.v22. i28.6527

24. Malta DC, Abreu DMX de, Moura L de, Lana GC, Azevedo G, França $E$. Trends in corrected lung cancer mortality rates in Brazil and regions. Rev Saude Publica [Internet] 2016 [Accessed in 2020 Ju 25];50(33):1-9. https://doi.org/10.1590/S1518-8787.2016050006209

25. Araujo LH, Baldotto C, Castro Jr. G, Katz A, Ferreira CG, Mathias C, et al. Lung cancer in Brazil. J Bras Pneumol [Internet] 2018 [Accessed in 2020 Jul 25];44(1):55-64. https://doi.org/10.1590/ s1806-37562017000000135

26. Oliveira MM, Latorre MRDO, Tanaka LF, Rossi BM, Curado MP. Disparidades na mortalidade de câncer colorretal nos estados brasileiros. Rev Bras Epidemiol [Internet] 2018 [Accessed in 2020 Jul 25];21:e180012. https://doi.org/10.1590/1980-549720180012

27. Ouakrim DA, Pizot C, Boniol M, Malvezzi M, Boniol M, Negri E, et al. Trends in colorectal cancer mortality in Europe: retrospective analysis of the WHO mortality database. BM] [Internet] 2015 [Accessed in 2020 Jul 25];351:h4970. https://doi.org/10.1136/bmj.h4970

28. Bojer AS, Roikjær O. Elderly patients with colorectal cancer are oncologically undertreated. Eur J Surg Oncol [Internet] 2015 [Accessed in 2020 Jul 25];41(3):421-5. https://doi.org/10.1016/j. ejso.2014.10.065

29. Blair CK, Jacobs Jr. DR, Demark-Wahnefried W, Cohen HJ, Morey $\mathrm{MC}$, Robien $\mathrm{K}$, et al. Effects of cancer history on functional age and mortality. Cancer [Internet] 2019 [Accessed in 2020 Jul 25];125(23):4303-9. https://doi.org/10.1002/cncr.32449

30. Carvalho JB, Paes NA. Taxas de mortalidade por câncer corrigidas para os idosos dos estados do Nordeste brasileiro. Cien Saude Colet [Internet] 2019 [Accessed in 2020 Jul 25];24(10):3857-66. https://doi.org/10.1590/1413-812320182410.03612018 